\title{
Battling the Methicillin-Resistant Staphylococcus aureus Biofilm Challenge with Vancoplus
}

\author{
Manu Chaudhary and Anurag Payasi* \\ Venus Medicine Research Centre, Hill Top Industrial Estate, Bhatoli Kalan, Baddi, H.P.-173205 India
}

\begin{abstract}
The present study was conducted with the aim to find the prevalence of biofilm formation ability among methicillin resistant Staphylococcus aureus (MRSA) isolates and to assess the activities of commonly used drugs against biofilm producing MRSA. Evaluation of prevalence of genes involved in MRSA biofilm production and their gene expression was also studied.

Of 55 MRSA, 47 isolates were biofilm producers and 8 isolates were non-biofilm producers. Of 47 biofilm producers, $24(51.0 \%), 14(29.8 \%)$ and $9(19.1 \%)$ produced strong (OD570 $\geq 0.5)$, medium (OD570 $\geq 0.2$ to $<0.5)$, weak (OD570 0 to <0.2) biofilm, respectively. Of the 47 isolates, eight determinants (genes) (eno, hla, hlb, clfA, fnaA, icaA, agrll and sar) were found predominantly among 70 to $80 \%$ isolates whereas cna was observed only in $21.3 \%$, finbB in $10.6 \%$ and ebps in $32 \%$ isolates. Amongst the strong biofilm producers (51\%), the lowest MIC values obtained with Vancoplus $(2-4 \mu \mathrm{g} / \mathrm{ml})>$ linezolid $(128$ to $256 \mu \mathrm{g} / \mathrm{ml})>$ daptomycin, clindamycin and teicoplanin $(256$ to $512 \mu \mathrm{g} / \mathrm{ml})$. Biofilms eradication rate was also observed in the same order with Vancoplus $(87 \%)>$ linezolid $(51.8 \%)$ $>$ clindamycin $(31.9 \%)>$ daptomycin $(27.5 \%)>$ teicoplanin $(26.5 \%)$. Our results showed that the percentage of finbA, hla, eno, clfA and fib genes expressions down-regulation after Vancoplus treatment was $64.0 \pm 5.9,63.8 \pm 5.8,73.0$ $\pm 7.4,72.8 \pm 7.8$ and $71.9 \pm 7.8 \%$, respectively as compared to the control among strong biofilm producing MRSA whereas teicoplanin produced only $30.3 \pm 2.7$ to $34.5 \pm 3.8 \%$ down regulation in fnbA, hla, eno, clfA and fib genes expression. The other comparator drugs, vancomycin, linezolid and daptomycin, demonstrated variable effects on these genes varying from $4.9 \pm 3.9$ to $30.3 \pm 2.7 \%$.
\end{abstract}

Our data showed that Vancoplus has significantly enhanced activity against MRSA biofilm producing isolates as compared to other drugs. Therefore, use of this antibiotic should be considered to treat the infections caused by biofilm producing MRSA.

Keywords: Biofilm; Clinical isolate; MIC; MBEC; Vancoplus

\section{Introduction}

Staphylococcus aureus is among the 5 most common pathogens that constitutes normal skin and nasal flora in at least 25 to $30 \%$ of healthy humans and is associated with large proportions of hospitalacquired and community acquired infections ranging from superficial wound infections to life-threatening deep infections such as septicemia, endocarditis and toxic shock syndrome [1-3]. Phenomenon of $S$. aureus infection is becoming more worrisome with the emergence of antibiotic resistant strain in particular methicillin-resistant $S$. aureus (MRSA) [4]. S. aureus has been reported to form biofilms on various surfaces, including medical devices and host tissues [5]. The S. aureus with biofilm forming ability is capable of causing a number of diseases, including infective endocarditis, osteomyelitis, foreign body-related infections, catheters associated Urinary Tract Infections (UTIs), and ventilator associated pneumonia and blood stream infections closely related to intravascular devices [5-8].

Biofilms, surface associated sessile bacterial communities, are formed when planktonic cells colonize to a surface, aggregate and grow into multicellular colonies, and embed themselves in an exopolysaccharide [9]. In addition to a large number of cell surface associated proteins, secreted proteins, Polysaccharide Intercellular Adhesin (PIA) and intracellular adhesin A, D, B and C (icaA, icaD, icaB and icaC) which are synthesized by products of the intercellular adhesin $\mathrm{A}, \mathrm{D}, \mathrm{B}$ and $\mathrm{C}$ (icaA, icaD, icaB and icaC) operon are also required for biofilm formation in staphylococci [5-8].

The cell surface associated proteins allow $S$. aureus to interact with host extracellular ligands, such as elastin binding protein (EbpS), laminin binding protein (Eno), collagen binding protein (Cna), fibronectin binding proteins A and B (FinbA, FinbB), fibrinogen binding protein (Fib), clumping factors A and B (ClfA, ClfB) [7,1012]. The secreted proteins include tissue degrading enzymes and toxins [13]. Recently, a-toxin (Hla) has been shown to play integral role in biofilm formation [14]. Production of these factors in S. aureus which are responsible for adherence, colonization and biofilm formation is controlled by accessory gene regulators including Agr, Sar and others [15]. Based on the agr variations, S. aureus strains can be divided into 4 groups menstrual Toxic Shock Syndrome (TSS) strains belong to agr groups I [16], all the strains causing leucocidin induced necrotizing pneumonia belong to agr group III [17], most intermediate level glycopeptide resistance strains belong to agr group II [18] and most efoliatin producing strains belong to agr group II [19].

According to Del P et al. [20] more than 65\% of hospital-acquired

*Corresponding author: Dr. Anurag Payasi, Venus Medicine Research Centre, Hill Top Industrial Estate, Bhatoli, Kalan, Baddi, H.P. - 173205 India, Tel: 91-1795302072; Fax: 91-1795-302133; E-mail: ccmb@vmrcindia.com

Received September 12, 2014; Accepted October 17, 2014; Published October 24,2014

Citation: Chaudhary M, Payasi A (2014) Battling the Methicillin-Resistant Staphylococcus aureus Biofilm Challenge with Vancoplus. J Microb Biochem Technol S10: 001. doi:10.4172/1948-5948.S10-001

Copyright: (c) 2014 Chaudhary M, et al. This is an open-access article distributed under the terms of the Creative Commons Attribution License, which permits unrestricted use, distribution, and reproduction in any medium, provided the original author and source are credited 
infections are caused by the organisms that have the capacity of producing biofilms. A study that was carried out in China, also reported $66 \%$ prevalence of biofilm-forming MRSA. The increasing incidence of biofilm producing MRSA in clinical infections has received increasing interest due to characterization of genes involved in biofilm formation $[21,22]$. The antibiotics such as methicillin, oxacillin and nafcillin, macrolides, tetracycline and aminoglycosides are being used to treat the infections caused by biofilm producing MRSA but they are getting resistant [23]. Now, glycopeptide antibiotic vancomycin is the remaining effective therapy. However, $76 \%$ treatment failure rate with vancomycin has been reported [24]. The emerging resistance towards vancomycin has limited the use of vancomycin and imposed a major concern to the global health community and reinforced the critical need for new methods of control and treatment of biofilm infections. In view of the growing consequences of biofilm producing MRSA and their resistance to commonly used drug, Venus Remedies Limited, India has developed a combination of ceftriaxone and vancomycin named as Vancoplus (US patent no;7960337, Japan patent no: 4918502). The current study was designed to investigate the biofilm formation ability among MRSA isolates and to assess the activities of commonly used drugs against biofilm producing MRSA. Evaluation of prevalence of genes involved in MRSA biofilm production and their gene expression by semi-quantitative PCR would be more advantageous in determining their relation.

\section{Materials and Methods}

\section{Antibacterial agents}

The following antibiotics were used in this study: a novel antibiotic adjuvant entity ceftriaxone sodium and vancomycin hydrocloride with VRP1020 (Vancoplus), teicoplanin, linezolid, daptomycin and clindamycin. All the drugs were reconstituted in water for injection except Vancoplus which was reconstituted in solvent provided with the pack as per manufacturer's instructions. Working solutions were prepared using Mueller Hinton broth (MHB, Himedia, Mumbai, India), and serial two fold dilutions were made using Cation-Adjusted Mueller-Hinton broth (CAMH, Himedia, Bombay, India) in wells of 96-well plate.

\section{Bacterial isolates collection and their identification}

A total of 70 clinical isolates of $S$. aureus were collected from various hospitals of North India including Vijayanagara Institute of Medical Sciences, Bareilly, Utter Pradesh, India; Sanjay Gandhi Postgraduate Institute, Lucknow, Utter Pradesh, India and Government Medical College and Hospital, Chandigarh, India. Initial inoculum of these isolates was made on blood agar plates and incubated at $37^{\circ} \mathrm{C}$ for $24 \mathrm{~h}$. Identification of the $S$. aureus was confirmed by Gram staining, catalase, oxidase, coagulase and growth characteristics on mannitol-salt agar. MRSA isolates were detected by the presence of the mecA gene as described earlier [25].

\section{Antimicrobial susceptibility testing}

Minimum Inhibitory Concentration (MIC) of each drug was determined by the broth dilution method according to the Clinical and Laboratory Standards Institute [26]. The MICs of the drugs represent the lowest concentration at which bacteria fail to grow.

\section{In vitro biofilm formation assay}

Biofilm forming ability of MRSA was investigated according to the method described earlier [27]. Briefly, $250 \mu \mathrm{l}$ of each MRSA isolate diluted 1:1000 in medium were inoculated in 96 wells polystyrene microtitre plates and incubated for $94 \mathrm{~h}$ at $37^{\circ} \mathrm{C}$ without shaking. After development of biofilm, non-adherent bacteria cells were removed and washed twice with $200 \mu \mathrm{l}$ of sterile phosphate buffer saline (PBS; pH 7.0), dried in an inverted position at room temperature under laminar air flow and stained with $300 \mu \mathrm{l}$ of crystal violet (2\%) for $45 \mathrm{~min}$. It is then washed 3 times with distilled water to remove excess stain. For destaining, $300 \mu \mathrm{l}$ of ethanol: acetic acid $(95: 5 \mathrm{v} / \mathrm{v})$ was added to each well. Hundred microlitre of this solution was transferred to another 96 wells plate and absorbance was measured at $570 \mathrm{~nm}$ using Elisa reader (Merck, USA). As a control, uninoculated medium was used. The mean OD570 value from control wells subtracted from the mean OD570 value of tested wells. The degree of biofilm production was classified in three categories: strong (OD570 $\geq 0.5)$, medium $(\mathrm{OD} 570 \geq 0.2$ to $<0.5)$ and weak (OD570 0 to $<0.2)$ [28]. Each test was done in triplicate.

\section{Minimum biofilm eradication concentrations (MBECs) determination}

MBECs of drugs were determined as described earlier [29]. Briefly, after development of biofilms in wells, the wells were washed with phosphate buffer saline (PBS; $\mathrm{pH} 7.0$ ) to remove non-adherent bacterial cells and added $200 \mu \mathrm{l}$ of each antibiotic of 2-fold dilutions (from 2 to 4096 $\mu \mathrm{g} / \mathrm{ml}$ ) and incubated for $24 \mathrm{~h}$ at $37^{\circ} \mathrm{C}$. The MBECs values represent the lowest dilution at which bacteria embedded in biofilm failed to regrow. All samples were run in duplicate and one lane served as a positive control and another lane with media served as negative control.

\section{Effect of drugs on biofilm}

To study the effect of drugs, after development of biofilms, the biofilms were treated with half concentrations of MBECs of drugs for $12 \mathrm{hrs}$. After treatment, assessment of drug efficacy was performed by two independent methods: counting of bacterial cells before and after treatment with different antibiotics and crystal violet staining.

For counting of bacteria embedded in biofilm, free floating bacterial cells from the wells after $12 \mathrm{hrs}$ of drug treatment were completely removed and $200 \mu \mathrm{l}$ of PBS were added to each well to remove remaining biofilm from the wells by ultrasonic disruption for $5 \mathrm{~min}$. The viable counts were determined on MHA plates. The same procedure was used for control plates to calculate the numbers of cells/well.

For staining of biofilm, after drug treatment and incubation, the antibiotics were removed from wells carefully without disturbing the cells in biofims and stained as mentioned above.

\section{DNA isolation}

DNA from selected clinical isolates was isolated by using the method explained below. Five $\mathrm{ml}$ of each MRSA overnight grown culture in soybean casein digest medium (SCDM; Hi-Media, Mumbai, India) was centrifuged at $5000 \mathrm{rpm}$ for $5 \mathrm{~min}$ at $25^{\circ} \mathrm{C}$, washed twice in phosphate buffer saline ( $\mathrm{pH} \mathrm{7.2)}$ and transferred to a $2 \mathrm{ml}$ micro-centrifuge tube. Then $0.2 \mathrm{ml}$ of the solution containing $25 \mathrm{~mm}$ Tris buffer $(\mathrm{pH} 8), 10 \mathrm{mM}$ EDTA (pH 8) and $50 \mathrm{mM}$ glucose was added. To this, $0.4 \mathrm{ml}$ of solution containing $1 \%$ sodium dodecyl sulfate (SDS) and $0.2 \mathrm{~N} \mathrm{NaOH}$ was added. The tubes were then gently inverted for 2-3 times and allowed to stand for $5 \mathrm{~min}$ at $28 \pm 2^{\circ} \mathrm{C}$. Finally, $0.3 \mathrm{ml}$ of chilled solution of $3 \mathrm{M}$ potassium acetate and $5 \mathrm{M}$ glacial acetic acid were added and allowed to stand on ice for 10 minutes. After centrifugation (14000 rpm, $2 \mathrm{~min}$ ) pellet was dissolved in $0.5 \mathrm{ml}$ of $0.05 \mathrm{M}$ Tris-EDTA buffer ( $\mathrm{pH} \mathrm{8.0)}$ ), incubated at $65^{\circ} \mathrm{C}$ for $2 \mathrm{~min}$ and $0.5 \mathrm{ml}$ of phenol-chloroform-isoamyl alcohol (25:24:1) was added and shaken thoroughly for $10 \mathrm{~min}$ and then centrifuged (14000 rpm, $3 \mathrm{~min}$ ). The DNA was precipitated by adding $1 \mathrm{ml}$ of ice-cold $70 \%$ ethanol to the supernatant. The quality of 
DNA was checked on 1.0\% agarose gel electrophoresis. DNA purity and concentration were assayed in a spectrophotometer (260/280).

\section{Polymerase Chain Reaction (PCR) assay}

PCR assays were carried out to detect the various genes in the biofilm producing MRSA isolates. The primers used in this study are summarized in Table 1. All the respective primers were obtained from Sigma Aldrich Chemicals Pvt. Ltd., Bangalore, India. For PCR amplifications, about $200 \mathrm{pg}$ of DNA was added to $20 \mu \mathrm{l}$ mixture containing $0.5 \mathrm{mM}$ of dNTPs, $1.25 \mu \mathrm{M}$ of each primer and $0.5 \mu \mathrm{l} /$ unit of Taq polymerase (Bangalore Genei) in 1x PCR buffer. Amplification was performed in an Eppendorf thermal cycler (Germany). The amplified products were separated in $1.0 \%$ agarose gel containing $2.5 \mu \mathrm{lof} 10 \mathrm{mg} /$ $\mathrm{ml}$ ethidium bromide. The gel was run at 70 volt for $1 \mathrm{~h}$. The gel images were taken under ultraviolet light using gel documentation system (BioRad, USA). A 100 bp ladder (Bangalore Genie) was used to measure the molecular weights of amplified products.

\section{RNA isolation}

Total RNA from untreated and treated MRSA strains with various drugs at their half of MIC was extracted using the method described elsewhere [30]. Briefly, two milliliter of overnight grown MRSA strains was centrifuged at $5000 \mathrm{rpm}$ for $5 \mathrm{~min}$ at $4^{\circ} \mathrm{C}$ and pellet was washed with $1 \mathrm{X}$ TE buffer ( $\mathrm{pH} 8.0$ ), suspended in $1 \mathrm{ml}$ of TE buffer containing $0.2 \%$ Triton X-100. The suspension was incubated at $100^{\circ} \mathrm{C}$ for $10 \mathrm{~min}$ and thereafter immediately placed on an ice bath. After incubation, an equal volume of chloroform : methanol $(2: 1)$ mixture was added, mixed thoroughly and centrifuged at $12000 \mathrm{rpm}$ at $4^{\circ} \mathrm{C}$ for $10 \mathrm{~min}$. This step was repeated twice. Finally, RNA was precipitated by addition of 2 volumes of pre-chilled $100 \%$ ethanol into the supernatant and mixture was incubated at $-20^{\circ} \mathrm{C}$ for 4 hour and then centrifuged at $12000 \mathrm{rpm}$ for $10 \mathrm{~min}$ at $4^{\circ} \mathrm{C}$. The pellet was air dried for $5 \mathrm{~min}$ and re dissolved in $50 \mu \mathrm{l}$ of Diethyl pyrocarbonate (DEPC) water. The purity of RNA was confirmed by measuring the absorbance at $260 / 280$ ratio which came approximately 1.9 as indicator of pure RNA. RNA was stored at $-70^{\circ} \mathrm{C}$ until use.

\section{cDNA synthesis}

Total RNA $(2 \mu \mathrm{g})$ was then converted to first strand cDNA as follows: two microgram of RNA was combined with $1 \mu$ of oligodT primer and $9.2 \mu \mathrm{l}$ of water and then mixture was incubated at $65^{\circ} \mathrm{C}$ for 5 mins. After incubation, following reagents were added sequentially: 4.0 $\mu \mathrm{l}$ of 5X RT buffer, $1.0 \mu \mathrm{l}$ of $0.1 \mathrm{M}$ DTT, $0.5 \mu \mathrm{l}$ of $10 \mathrm{mM}$ dNTP and 0.3 $\mu \mathrm{l}$ of $20 \mathrm{U} / \mu \mathrm{l}$ Moloney Murine Leukemia Virus Reverse Transcriptase (MMLVRT) mixed well and the mixture was subsequently incubated at $37^{\circ} \mathrm{C}$ for $60 \mathrm{~min}$. The reaction was stopped by heating at $70^{\circ} \mathrm{C}$ for 10 min. The resultant solution was cDNA which can be used for further study.

\section{RT-PCR analysis}

RT-PCR was performed using the cDNA. The primers for the selected genes were the same as mentioned in Table 1 . $\beta$-actin primer was used as internal control and following sequences were used: $\beta$-actin-F-5'-GAAGCATTTGCGGTGGACCAT-3' and $\beta$-actin-R-5'TCCTGTGGCATCCACCAAACT-3'. For PCR amplifications, about 3 $\mu \mathrm{l}$ of cDNA was added to $20 \mu \mathrm{l}$ mixture containing $0.5 \mathrm{mM}$ of dNTPs, $1.25 \mu \mathrm{M}$ of each primer and $3.0 \mathrm{U}$ of Taq polymerase (Bangalore Genei) in 1x PCR buffer. Amplification was performed in an Eppendorf thermocycler (Germany) with the same cycling parameters: 2 min at $94^{\circ} \mathrm{C}$ and 25 cycles at $94^{\circ} \mathrm{C}$ for $30 \mathrm{~s}, 55^{\circ} \mathrm{C}$ for $30 \mathrm{~s}, 72^{\circ} \mathrm{C}$ for $30 \mathrm{~s}$ and one cycle for $10 \mathrm{~min}$ at $72^{\circ} \mathrm{C}$. PCR products were then electrophoresed on a $1.0 \%$ agarose gel containing ethidium bromide. After electrophoresis, density of PCR products was measured using image J software.

\section{Effect of drugs on genes finb $A, f i b, c l f A$, eno and hla expression}

To evaluate the effects of drugs on expressions of $f n b A, f i b, c l f A$, eno and hla genes, MRSA strains were treated with all the selected drugs, Vancoplus, clindamycin, linezolid, teicoplanin and daptomycin, at their half of MIC for $24 \mathrm{~h}$. Following treatment,first strand cDNA from RNA was synthesized as mentioned above. First strand cDNA was synthesized as mentioned above. The same strain without drug treatment served as a control. All experiments were carried out in triplicate and representative data are presented.

\section{Results}

\section{Screening of MRSA}

Out of 70 clinical isolates, $55(78.6 \%)$ isolates were identified to be MRSA as confirmed by amplification of mecA gene. The prevalence of

\begin{tabular}{|c|c|c|c|}
\hline Gene & Nucleotide sequence & Amplicon size (bp) & References \\
\hline \multirow{2}{*}{ eno } & 5'-ACGTGCAGCAGCTGACT-3' & \multirow{2}{*}{302} & \multirow{2}{*}{ Tristan et al. (2003) } \\
\hline & 5'-CAACAGCATYCTTCAGTACCTTC-3' & & \\
\hline \multirow{2}{*}{ ebpS } & 5'-CATCCAGAACCAATCGAAGAC-3' & \multirow{2}{*}{186} & \multirow{2}{*}{ Mariana et al., 2009} \\
\hline & 5'-CTTAACAGTTACATCATCATGTTTATCTTTG-3' & & \\
\hline \multirow{2}{*}{$f n b A$} & 5'-GTGAAGTTTTAGAAGGTGGAAAGATTAG-3' & \multirow{2}{*}{643} & \multirow{2}{*}{ Tristan et al., 2009} \\
\hline & 5'-GCTCTTGTAAGACCATTTTTCTTCAC-3' & & \\
\hline \multirow{2}{*}{$f n b B$} & 5'-GTAACAGCTAATGGTCGAATTGATACT-3' & \multirow{2}{*}{524} & \multirow{2}{*}{ Tristan et al. (2003) } \\
\hline & 5'-CAAGTTCGATAGGAGTACTATGTTC-3' & & \\
\hline \multirow{2}{*}{ fib } & 5'-CTACAACTACAATTGCCGTCAACAG-3' & \multirow{2}{*}{404} & \multirow{2}{*}{ Tristan et al. (2003) } \\
\hline & 5'-GCTCTTGTAAGACCATTTTCTTCAC-3' & & \\
\hline \multirow{2}{*}{ clfA } & 5'-ATTGGCGTGGCTTCAGTGCT-3' & \multirow{2}{*}{292} & \multirow{2}{*}{ Tristan et al. (2003) } \\
\hline & 5'-CGTTTCTTCCGTAGTTGCATTTG-3' & & \\
\hline \multirow{2}{*}{$c l f B$} & 5'-ACATCAGTAATAGTAGGGGGCAAC-3' & \multirow{2}{*}{205} & \multirow{2}{*}{ Tristan et al. (2003) } \\
\hline & 5'-TTCGCACTGTTTGTGTTTGCAC-3' & & \\
\hline \multirow{2}{*}{ hla } & 5'-CTGGCCTTCAGCCTTTAAGG-3' & \multirow{2}{*}{455} & \multirow{2}{*}{ Ando et al. (2004) } \\
\hline & 5'-CTGTAGCGAAGTCTGGTGAAA-3' & & \\
\hline \multirow{2}{*}{ cna } & 5'-GTCAAGCAGTTATTAACACCAGAC-3' & \multirow{2}{*}{423} & \multirow{2}{*}{ Tristan et al. (2003) } \\
\hline & 5'-AATCAGTAATTGCACTTTGTCCACTG-3' & & \\
\hline
\end{tabular}

Table 1: Nucleotide sequences and anticipated amplicon sizes for the $S$. aureus gene-specific oligonucleotide primers. 
MRSA was maximum in pus (86.2\%) followed by urine (75\%), blood $(73.3 \%)$ and wound swab (71.45\%).

\section{Biofilm formation assay}

Of 55 MRSA, 47 isolates were biofilm producers and 8 isolates were non-biofilm producers. Of 47 biofilm producers, $24(51.0 \%)$, $14(29.8 \%)$ and $9(19.1 \%)$ produced strong (OD570 $\geq 0.5)$, medium (OD570 $\geq 0.2$ to $<0.5$ ), weak (OD570 0 to $<0.2$ ) biofilm, respectively. The highest number of strong biofilm producer was recovered from pus $58.3 \%(14 / 24)$ followed by urine $20.8 \%(5 / 24)$, blood $12.5 \%(3 / 24)$ and wound swab $8.3 \%(2 / 24)$. The strong biofilm producers MRSA strains were used for further study.

\section{Analysis of genes encoding cell surface proteins and toxins}

Of the 47 isolates, eight determinants (genes) (eno, hla, hlb, clfA, fnaA, icaA, agrII and sar) were found predominantly among 70 to $80 \%$ isolates whereas cna was observed only in $21.3 \%$, finbB in $10.6 \%$ and ebps in $32 \%$ isolates (Figure 1).

\section{Relationship between biofilm formation and virulence determinants}

The icaA gene was excluded from the evaluation as all the isolates possessed this gene. As shown in Table 2, the mean OD570 value was higher in eno, hla, clfA, finbA and fib positive isolates compared to eno, hla, clfA, finbA and fib isolates. The percentage of hla, hlb and fnaA was $100 \%$ among strong biofilm producers whereas other determinants vary from 87 to $95 \%$. The percentage of hla was the highest in medium biofilm producing MRSA (78.6\%) while other ranged from 33 to $77 \%$. None of the isolates was positive with hlb. The percentage of hlb and fnaA in weak biofilm producing MRSA was $100 \%$ and $33.3 \%$ while none of the isolates was positive with hla. These results suggest that MRSA isolates possessing $h l a, h l b, f n a A$ and $c l f A$ genes had greater capacities for biofilm formation than those of lacking these 3 genes (Figure 2).

\section{MIC}

As shown in Table 3, Vancoplus emerged as the most effective antibacterial agent with MIC values 2 to $4,0.5$ to 1 and 0.125 to $0.25 \mu \mathrm{g} /$ $\mathrm{ml}$ in strong, medium and weak biofilm producing isolates, respectively. Second most active agent was linezolid followed by teicoplanin, daptomycin and clindamycin.

\section{MBEC}

The MBEC of Vancoplus for strong, medium and weak biofilm producers MRSA was approximately $2 \mathrm{X}, 3 \mathrm{X}$ and $2 \mathrm{X}$ of MIC, indicating that 2 to 3 times more Vancoplus is required to kill the bacteria in biofilms than that was required to inhibit planktonic bacterial cells. The MBEC of linezolid varied from 1024 to 2048, 256 to 512 and 64 to $128 \mu \mathrm{g} / \mathrm{ml}$ for strong, medium and weak biofilm producing MRSA, respectively. The MBECs of daptomycin, teicoplanin and clindamycin were $>2048,1024$ to 2048 and 128 to $512 \mu \mathrm{g} / \mathrm{ml}$ for strong, medium and weak biofilm producing MRSA, respectively which is 3 to 4 times higher than their respective MIC values (Table 4).

\section{Biofilm breaking}

Drugs were treated with half MBEC on preformed biofilms of selected strong biofilm producing strains, the data (Table 5) shows that only Vancoplus significantly reduced viable counts of bacterial cells embedded in biofilm of MRSA with log reduction value 5.31. Linezolid was the second most effective drugs with log reduction value 3.47 . The other drugs showed only 2.24 to 2.25 logs reduction in bacteria after

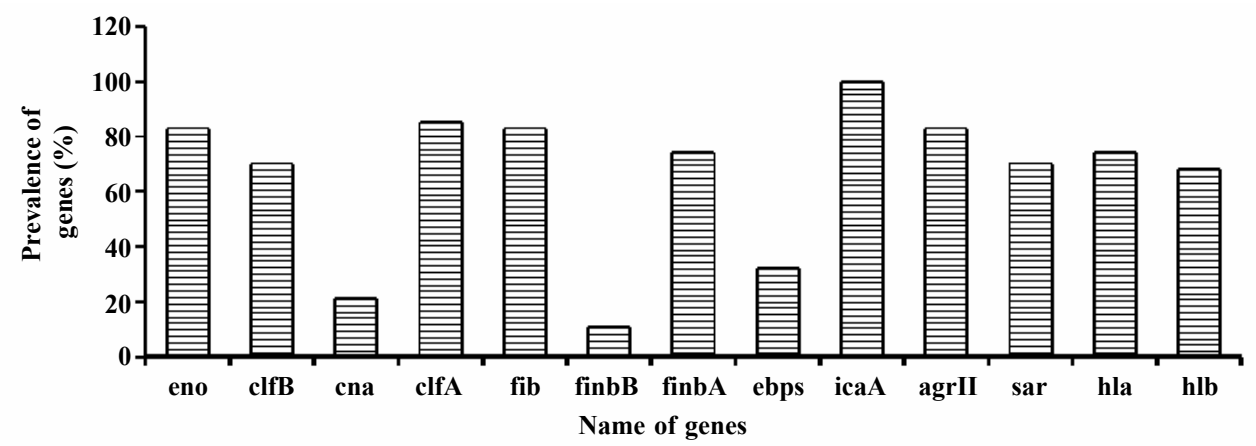

Figure 1: Prevalence of genes producing cell surface proteins and toxins required for biofilm formation among MRSA isolates.

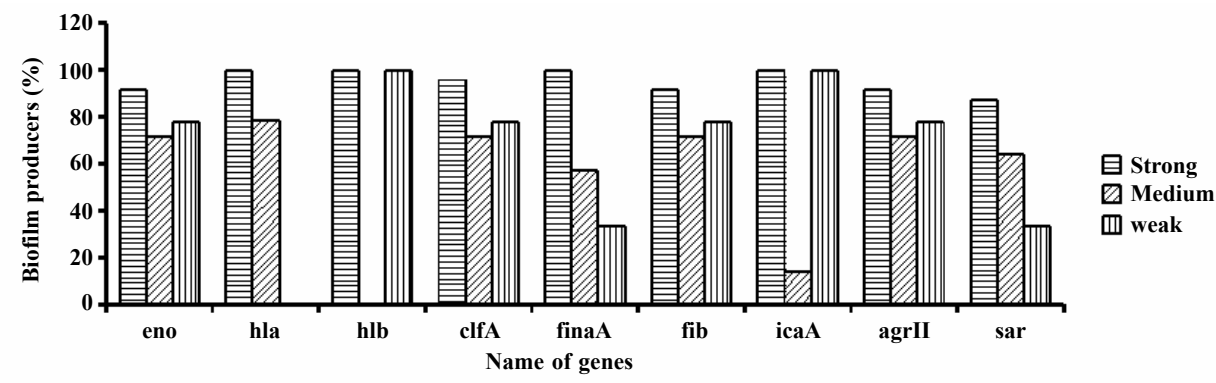

Figure 2: Percentage of eno, hla, hlb, clfA, fib, finbA, icaA, agrll and sar positive isolates among MRSA isolates that belong to strong, medium and weak biofilm producer. 


\begin{tabular}{|c|c|c|}
\hline Virulence determinants & Total no. of isolates (47) & $\mathbf{O D}_{\mathbf{5 7 0}}$ (mean $\left.\pm \mathbf{S D}\right)$ \\
\hline eno-positive & 39 & $0.721 \pm 0.081$ \\
\hline eno-negative & 8 & $0.301 \pm 0.089$ \\
\hline hla-positive & 35 & $0.465 \pm 0.063$ \\
\hline hla-negative & 2 & $0.185 \pm 0.020$ \\
\hline clfA-positive & 40 & $0.694 \pm 0.060$ \\
\hline clfA-negative & 7 & $0.169 \pm 0.043$ \\
\hline clfB-positive & 33 & $0.321 \pm 0.068$ \\
\hline clfB-negative & 5 & $0.258 \pm 0.098$ \\
\hline finbA-positive & 35 & $0.612 \pm 0.084$ \\
\hline finbA-negative & 12 & $0.235 \pm 0.069$ \\
\hline agrll-positive & 39 & $0.264 \pm 0.049$ \\
\hline agrll-negative & 8 & $0.231 \pm 0.035$ \\
\hline sar-positive & 33 & $0.284 \pm 0.087$ \\
\hline sar-negative & 14 & $0.268 \pm 0.065$ \\
\hline fib-positive & 39 & $0.635 \pm 0.075$ \\
\hline fib-negative & 8 & $0.168 \pm 0.035$ \\
\hline C.
\end{tabular}

Table 2: Corelation between biofilm forming capacities and cell surface proteins and toxins.

\begin{tabular}{|l|c|c|c|}
\hline \multirow{2}{*}{ Drug Name } & \multicolumn{3}{|c|}{ MIC ( $\boldsymbol{\mu g} / \mathbf{m l})$} \\
\cline { 2 - 4 } & Strong & Medium & Weak \\
\hline Daptomycin & 256 to 512 & 64 to 128 & 16 to 32 \\
\hline Teicoplanin & 256 to 512 & 64 to 128 & 32 to 64 \\
\hline Linezolid & 128 to 256 & 32 to 64 & 8 to 16 \\
\hline Vancoplus & 2 to 4 & 0.5 to 1 & 0.125 to 0.25 \\
\hline Clindamycin & 256 to 512 & 64 to 128 & 16 to 32 \\
\hline
\end{tabular}

Table 3: Minimum inhibitory concentration of drugs against biofilm producing MRSA.

\begin{tabular}{|l|c|c|c|}
\hline \multirow{2}{*}{ Drug Name } & \multicolumn{3}{|c|}{ MIC ( $\mathbf{\mu g} / \mathbf{m l})$} \\
\cline { 2 - 4 } & Strong & Medium & Weak \\
\hline Daptomycine & $>2048$ & 1024 to 2048 & 128 to 256 \\
\hline Teicoplanin & $>2048$ & 1024 to 2048 & 128 to 256 \\
\hline Linezolid & $1024-2048$ & 256 to 512 & 64 to 128 \\
\hline Vancoplus & 8 to 16 & 4 to 8 & 0.5 to 1 \\
\hline Clindamycin & $>2048$ & 1024 to 2048 & 128 to 256 \\
\hline
\end{tabular}

Table 4: Minimum biofilm eradication concentration of drugs against strong, medium and weak biofilm producing MRSA.

treatment. The staining of wells following treatment with half of MBEC of drugs also supports these results. The wells treated with Vancoplus showed $87 \%$ eradication of biofilm followed by linezolid $(51.8 \%$ eradication), clindamycin ( $31.9 \%$ eradication), daptomycin $(27.5 \%$ eradication) and teicoplanin (26.5\% eradication).

\section{Effects of drugs on finbA, fib, clfA, eno and hla gene expression}

For gene expression study, we selected those genes which were present predominantly among strong and medium biofilm producers strains. Our results showed that the percentage of finbA, hla, eno, clfA and $f i b$ genes expression down-regulation after Vancoplus treatment was $64.0 \pm 5.9,63.8 \pm 5.8,73.0 \pm 7.4,72.8 \pm 7.8$ and $71.9 \pm 7.8 \%$, respectively as compared to the control among strong biofilm producers MRSA whereas teicoplanin produced only $34.5 \pm 3.8,25.09 \pm 2.3,25.6$ $\pm 2.5,28.9 \pm 2.5$ and $30.3 \pm 2.7 \%$ down regulation in fnbA, hla, eno, clfA and fib genes expression. The other comparator drugs, clindamycin, linezolid and daptomycin, demonstrated variable effects on these genes varying from $4.9 \pm 3.9$ to $30.3 \pm 2.7 \%$ (Figure 3 ). Overall, Vancoplus was found to be significantly down regulating the genes required for biofilm formation hence controlling the biofilm formation.

\section{Discussion}

Over the past several decades, the incidence of resistant grampositive organisms has risen throughout the world. Among these, MRSA are predominant pathogens known to form biofilm on various surface [28] and believed to have an enormous impact on healthcare and are estimated to be associated with $65 \%$ of nosocomial infections [31].

In this study, $85.4 \%$ MRSA isolates were confirmed to be biofilm producers of which approximately 51\% (24/47) were strong biofilm producers, $19.1 \%$ and $14.5 \%$ of MRSA were weak biofilm and nonbiofilm producers, respectively which is in agreement with previous studies [32,33]. S. aureus is capable of adhering to a large variety of surfaces which is frequently mediated by protein adhesins of the family MSCRAMM (Microbial Surface Components Recognizing Adhesive Matrix Molecules). The collagen binding proteins, fibronectin binding proteins, clumping factors and fibrinogen binding proteins belong to this family $[7,10]$. In the current investigation, we observed that $>70 \%$ isolates possessed clfA, eno, fib, hla and finbA which were responsible for strong biofilm production whereas the prevalence of other cell surface proteins were less than $40 \%$. Of the studied determinants, clfA, eno, fib, hla and finbA were predominants in those isolates that had significant greater capacities for biofilm formation than clfA, eno, fib, hla and finbA negative isolates.

We also observed that icaA gene which is known to be involved in Polysaccharide Intracellular Adhesin (PIA) synthesis of staphylococci plays important role in cell to cell interaction during biofilm formation [5] and is present in all biofilm producers.

As universally reported, planktonic cells were found to be more susceptible than cells embedded in biofilm. This is because, once biofilm is formed, the bacteria undergo phenotypic changes that include increased production of extracellular polysaccharide, decreased metabolic rates and decreased multiplication. The decreased multiplication of bacteria is less susceptible to antibiotics by virtue of their reduced growth rates [34,35].

Vancomycin is a time dependent antibiotic and its clinical efficacy depends on various factors including inoculumn size, tissue distribution and protein binding effects $[36,37]$. Our results revealed that among the tested drugs, Vancoplus (combination of vancomycin plus ceftriaxone along with VRP1020) was found to be more active against planktonic bacteria (MIC 0.125 to $4 \mu \mathrm{g} / \mathrm{ml}$ ) as well as bacteria embedded in biofilm (MBECs 0.5 to $16 \mu \mathrm{g} / \mathrm{ml}$ ).

The enhanced activity of Vancoplus to planktonic bacteria may be due to synergistic action of ceftriaxone, vancomycin and VRP1020 (a non-antibiotic adjuvant which prevents degradation of antibiotics). Ceftriaxone inhibits bacterial cell wall synthesis by means of binding to the penicillin-binding proteins [38]. The MBECs values for Vancoplus is less compared to previous study where vancomycin MBEC was reported $>512 \mu \mathrm{g} / \mathrm{ml}$ against $S$. aureus [39]. This is probably may be due to VRP1020 which enhanced the penetration of antibiotics into the biofilms by breaking the exopolysaccharide structure through removal of $\mathrm{Ca}^{2+}$ ions required for biofilm structure [40]. Further, Vancoplus reduced 5.3 logs in bacterial count in bacterial cells embedded in biofilm with $87 \%$ biofilm eradication. As in previous studies [41,42], we also observed that teicoplanin and clindamycin are not much effective in bacterial cells embedded in biofilm. Contrary to previous study, our data demonstrated reduced activity of daptomycin and linezolid at high inoculumn of baterial populations [37]. 


\begin{tabular}{|l|c|c|c|c|}
\hline \multirow{2}{*}{ Drug Name } & Time (h) & $\begin{array}{c}\text { Biofilm concentration (cfu/peg)a before } \\
\text { treatment (A) }\end{array}$ & $\begin{array}{c}\text { Biofilm concentration (cfu/peg)b after } \\
\text { treatment (B) }\end{array}$ & MRSA \\
\cline { 2 - 4 } & & MRSA & $2.4 \times 10^{6}(6.38)^{\mathrm{a}}$ \\
\hline Daptomycin & 12 & $4.3 \times 10^{8}(8.63)^{\mathrm{a}}$ & $3.6 \times 10^{6}(6.55)^{\mathrm{a}}$ \\
\hline Teicoplanin & 12 & $6.2 \times 10^{8}(8.79)^{\mathrm{a}}$ & $1.8 \times 10^{5}(5.25)^{\mathrm{a}}$ \\
\hline Linezolid & 12 & $5.3 \times 10^{8}(8.72)^{\mathrm{a}}$ & 2.25 \\
\hline Vancoplus & 12 & $6.4 \times 10^{8}(8.80)^{\mathrm{a}}$ & $3.2 \times 10^{3}(3.50)^{\mathrm{a}}$ \\
\hline Clindamycin & 12 & $4.9 \times 10^{8}(8.69)^{\mathrm{a}}$ & $2.8 \times 10^{6}(6.44)^{\mathrm{a}}$ \\
\hline
\end{tabular}

This study was conducted only on strong biofilm producer strains.

Table 5: Effect of antibacterial agents on biofilm.

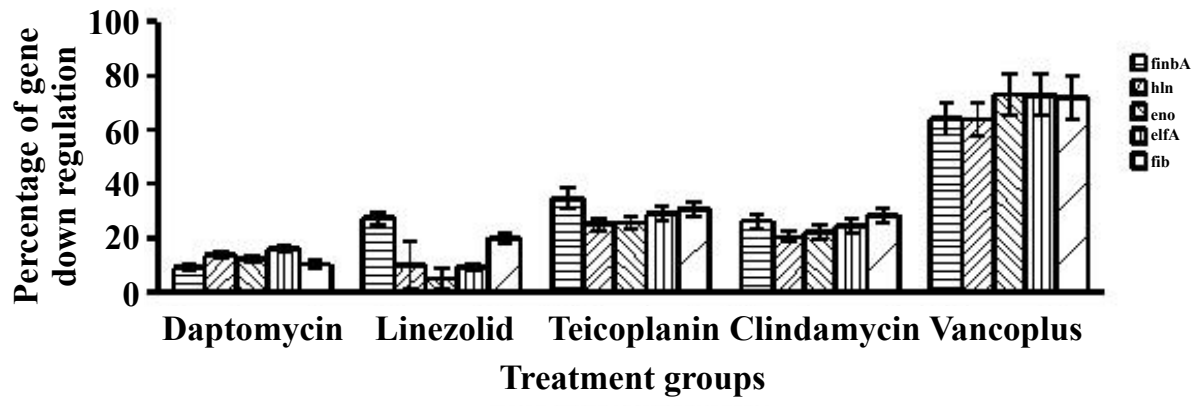

Figure 3: Downregulation of genes involved in biofilm formation.

It is interesting that Vancoplus demonstrated activity on these bacteria with MIC 0.125 to $4 \mu \mathrm{g} / \mathrm{ml}$ and MBECs of 0.5 to $16 \mu \mathrm{g} / \mathrm{ml}$. Since $29 \%$ of the Vancomycin is protein bound [43], the calculated maximum concentration of unbound drug in serum is $34 \mu \mathrm{g} / \mathrm{ml}$ [44]. Thus clinical doses of Vancoplus (free drug) will exceed the MBEC and should have activity against bacteria embedded in biofilm. The clinical achievable concentration of other comparator drugs are less compared to their MBECs hence these drugs may not be effective against the bacteria embedded in biofilm $[44,45]$. The clinical data study supports the use of Vancoplus in the treatment of lower respiratory tract infections, endocarditis, meningitis and bone infections (unpublished data). The animal model data suggest efficacy in the treatment of intra abdominal infection and meningitis [46,47].

Several previous studies have demonstrated the influences of subinhibitory concentrations of antimicrobial agents on the expression of various virulence factors which are produced by $S$. aureus and required for biofilm formation [48-50]. In our study, expression of all the selected genes was down regulated when MRSA positive for these genes were treated with different drugs. Hla is important for $S$. aureus biofilm formation and deficiency in Hla caused defects in biofilm formation [51]. Howden et al. [52] reported that on treatment of VISA clinical isolates with vancomycin drug significantly downregulated the expression of cell surface adhesion molecules and a number of genes involved in pathogenesis and toxin production (spa, finbA, finbB, efb). Furthermore, Schröder et al. [53] reported that on treatment of $S$. aureus isolate with novobiocin antibiotic showed decreased expression of finbA when analyzed with microarray and northern blot hybridization. In accordance with our study, Koszczol et al. [54] demonstrated that enolase (eno) was down-regulated following drug treatment. Clumping factor A (ClfA) was shown to be critical in mediating direct $S$. aureus platelet adhesion and in indirect binding via exogenously added fibrinogen [55]. During the early growth phase, ClfA was identified as the dominant staphylococcal adhesion receptor in both the presence and absence of exogenously added fibrinogen [55]. Numerous studies have demonstrated that treatment of $S$. aureus with temporin L, ovispirin-1 and dermaseptin K4-S4 peptides caused downregulation of several virulence factors and their regulators (saeRS and agr) including clfA and clfB. Beenken et al. [3] reported that fib gene showed down-regulation when treated with vancomycin in JH9 strain of $S$. aureus, these results are also in accordance with our study where we reported that fib gene get downregulated when culture of $S$. aureus treated with different antibiotics. These findings strongly suggest that changes in the regulation of transcription of these particular set of virulence determinants may represent an attractive therapeutic targets.

\section{Conclusion}

In conclusion, this work demonstrates combining ceftriaxone with vancomycin in presence of VRP1020 significantly reduces the MIC and MBEC values against strong biofilm producing MRSA isolates. Exposure to a sub inhibitory concentration of the Vancoplus significantly down regulated levels of expression of several genes encoding biofilm associated proteins, it was observed that the regulation and expression of certain virulence factors involved in pathogenesis in S. aureus are markedly downregulated in the presence of the Vancoplus, which is encouraging. Although Linezolid appeared to be the second best option after Vancoplus, but failed to eradicate biofilm effectively. This work also conclude the maximum biofilm eradication efficiency of Vancoplus and thus Vancoplus could be one of the best choice to eradicate the biofilm caused by these organisms and an effective therapeutic option for the treatment of biofilm producing MRSA strains.

\section{Acknowledgement}

Authors are thankful to sponsor, Venus Pharma GmbH, AM Bahnhof 1-3 D-59368, Werne, Germany, for providing financial assistance to carry out this study.

\section{References}

1. Otto M (2008) Staphylococcal biofilms. Curr Top Microbiol Immunol 322: 207 228.

2. Pace JL, Rupp ME, Finch RG (2006) Biofilms, infection and antimicrobial therapy. Boca Raton, FL: Taylor and Francis Group, 2006. Clin Infect Dis 43 1623. 
3. Beenken KE, Dunman PM, McAleese F, Macapagal D, Murphy E, et al. (2004) Global gene expression in Staphylococcus aureus biofilms. J Bacteriol 186 4665-4684.

4. Brady RA, Leid JG, Camper AK, Costerton JW, Shirtliff ME (2006) Identification of Staphylococcus aureus proteins recognized by the antibody-mediated immune response to a biofilm infection. Infect Immun 74: 3415-3426.

5. Götz F (2002) Staphylococcus and biofilms. Mol Microbiol 43: 1367-1378.

6. Gowrishankar S, Duncun Mosioma N, Karutha Pandian S (2012) CoralAssociated Bacteria as a Promising Antibiofilm Agent against MethicillinResistant and -Susceptible Staphylococcus aureus Biofilms. Evid Based Complement Alternat Med 2012: 862374.

7. Atshan SS, Nor Shamsudin M, Sekawi Z, Lung LT, Hamat RA, et al. (2012) Prevalence of adhesion and regulation of biofilm-related genes in different clones of Staphylococcus aureus. J Biomed Biotechnol 2012: 976972.

8. Yarwood JM, Bartels DJ, Volper EM, Greenberg EP (2004) Quorum sensing in Staphylococcus aureus biofilms. J Bacteriol 186: 1838-1850.

9. Murugan K, Usha M, Malathi P, Al-Sohaibani AS, Chandrasekaran M (2010) Biofilm forming multi drug resistant Staphylococcus spp. among patients with conjunctivitis. Pol J Microbiol 59: 233-239.

10. Kardas-Sloma L, Boëlle PY, Opatowski L, Brun-Buisson C, Guillemot D, et al. (2011) Impact of antibiotic exposure patterns on selection of communityassociated methicillin-resistant Staphylococcus aureus in hospital settings. Antimicrob Agents Chemother 55: 4888-4895.

11. Okesola AO (2011) Community-acquired methicillin-resistant Staphylococcus aureus--a review of literature. Afr J Med Med Sci 40: 97-107.

12. Rosenthal VD, Bijie H, Maki DG, Mehta Y, Apisarnthanarak A, et al. (2012) International Nosocomial Infection Control Consortium (INICC) report, data summary of 36 countries, for 2004-2009. Am J Infect Control 40: 396-407.

13. Novick RP (2000) Pathogenicity factors and their regulation, p. 392-407. In V. A. Fischetti, R. P. Novick, J. J. Ferretti, D. A. Portnoy, and J. I. Rood (ed.), Gram-positive pathogens. ASM Press, Washington, D.C.

14. Caiazza NC, O'Toole GA (2003) Alpha-toxin is required for biofilm formation by Staphylococcus aureus. J Bacteriol 185: 3214-3217.

15. Novick RP (2003) Autoinduction and signal transduction in the regulation of staphylococcal virulence. Mol Microbiol 48: 1429-1449.

16. Ji G, Beavis R, Novick RP (1997) Bacterial interference caused by autoinducing peptide variants. Science 276: 2027-2030.

17. Gillet $Y$, Issartel B, Vanhems P, Fournet JC, Lina G, et al. (2002) Association between Staphylococcus aureus strains carring gene for Pantone-valentine leukocidin and highly lethal necrotizing pneumonia in young immunocompetent patients. Lancet 2: 753-9.

18. Sakoulas G, Eliopoulos GM, Moellering RC Jr, Novick RP, Venkataraman L, et al. (2003) Staphylococcus aureus accessory gene regulator (agr) group II: is there a relationship to the development of intermediate-level glycopeptide resistance? J Infect Dis 187: 929-938.

19. Jarraud S, Lyon GJ, Figueiredo AM, Lina G, Vandenesch F, et al. (2000) Exfoliatin-producing strains define a fourth agr specificity group in Staphylococcus aureus. J Bacteriol 182: 6517-6522.

20. Del Papa MF, Hancock LE, Thomas VC, Perego M (2007) Full activation of Enterococcus faecalis gelatinase by a C-terminal proteolytic cleavage. J Bacteriol 189: 8835-8843

21. Cucarella C, Solano C, Valle J, Amorena B, Lasa I, et al. (2001) Bap, a Staphylococcus aureus surface protein involved in biofilm formation. J Bacteriol 183: 2888-2896

22. Cucarella C, Tormo MA, Knecht E, Amorena B, Lasa I, et al. (2002) Expression of the biofilm-associated protein interferes with host protein receptors of Staphylococcus aureus and alters the infective process. Infect Immun 70: 3180-3186.

23. Thati V, Shivannavar CT, Gaddad SM (2011) Vancomycin resistance among methicillin resistant Staphylococcus aureus isolates from intensive care units of tertiary care hospitals in Hyderabad. Ind J Med Res 134: 70408.

24. Howden BP, Ward PB, Charles PG, Korman TM, Fuller A, et al. (2004) Treatment outcomes for serious infections caused by methicillin-resistant
Staphylococcus aureus with reduced vancomycin susceptibility. Clin Infect Dis 38: $521-528$

25. Araki M, Kariyama R, Monden K, Tsugawa M, Kumon H (2002) Molecula epidemiological studies of Staphylococcus aureus in urinary tract infection. J Infect Chemother 8: 168-174.

26. Clinical and Laboratory Standards Institute (2013) Performance standards for antimicrobial susceptibility testing; twenty-first informational supplement. CLSI document M100-S23. Wayne, PA

27. Seno Y, Kariyama R, Mitsuhata R, Monden K, Kumon H (2005) Clinical implications of biofilm formation by Enterococcus faecalis in the urinary tract. Acta Med Okayama 59: 79-87.

28. Ando E, Monden K, Mitsuhata R, Kariyama R, Kumon H (2004) Biofilm formation among methicillin-resistant Staphylococcus aureus isolates from patients with urinary tract infection. Acta Med Okayama 58: 207-214.

29. Ceri H, Olson ME, Stremick C, Read RR, Morck D, et al. (1999) The Calgary Biofilm Device: new technology for rapid determination of antibiotic susceptibilities of bacterial biofilms. J Clin Microbiol 37: 1771-1776.

30. Sung YJ, Dolzhanskaya N, Nolin SL, Brown T, Currie JR, et al. (2003) The fragile $X$ mental retardation protein FMRP binds elongation factor $1 \mathrm{~A}$ mRNA and negatively regulates its translation in vivo. J Biol Chem 278: 15669-15678.

31. Potera C (1999) Forging a link between biofilms and disease. Science 283 1837, 1839.

32. Kaur DC, Khare AS (2013) Biofilm formation and antibiotic susceptibility pattern in MRSA strains in a tertiary care rural hospital. Indian J Basic Appl Med Res 3: $37-44$.

33. Wang L, Yu F, Yang L, Li Q, Zhang X, Zeng Y, et al. (2010) Prevalence of virulence genes and biofilm formation among Staphylococcus aureus clinical isolates associated with lower respiratory infection. Afr J Microbiol Res 4: 2566 2569.

34. Brown MR, Allison DG, Gilbert P (1988) Resistance of bacterial biofilms to antibiotics: a growth-rate related effect? J Antimicrob Chemother 22: 777-780.

35. Xu KD, McFeters GA, Stewart PS (2000) Biofilm resistance to antimicrobial agents. Microbiology $146: 547-549$

36. Kollef MH (2007) Limitations of vancomycin in the management of resistant staphylococcal infections. Clin Infect Dis 45 Suppl 3: S191-195.

37. Rybak MJ (2006) The pharmacokinetic and pharmacodynamic properties of vancomycin. Clin Infect Dis 42 Suppl 1: S35-39.

38. Schichor A, Bernstein B, Weinerman H, Fitzgerald J, Yordan E, et al. (1994) Lidocaine as a diluent for ceftriaxone in the treatment of gonorrhea. Does it reduce the pain of the injection? Arch Pediatr Adolesc Med 148: 72-75.

39. LaPlante KL, Mermel LA (2009) In vitro activities of telavancin and vancomycin against biofilm-producing Staphylococcus aureus, S. epidermidis, and Enterococcus faecalis strains. Antimicrob Agents Chemother 53: 3166-3169.

40. O'Connell DP, Nanavaty T, McDevitt D, Gurusiddappa S, Höök M, et al. (1998) The fibrinogen-binding MSCRAMM (clumping factor) of Staphylococcus aureus has a Ca2+-dependent inhibitory site. J Biol Chem 273: 6821-6829.

41. Monzón M, Oteiza C, Leiva J, Lamata M, Amorena B (2002) Biofilm testing of Staphylococcus epidermidis clinical isolates: low performance of vancomycin in relation to other antibiotics. Diagn Microbiol Infect Dis 44: 319-324.

42. Smith K, Perez A, Ramage G, Gemmell CG, Lang S (2009) Comparison of biofilm-associated cell survival following in vitro exposure of meticillin-resistant Staphylococcus aureus biofilms to the antibiotics clindamycin, daptomycin linezolid, tigecycline and vancomycin. Int J Antimicrob Agents 33: 374-378.

43. Zokufa HZ, Solem LD, Rodvold KA, Crossley KB, Fischer JH, et al. (1989) The influence of serum albumin and alpha 1-acid glycoprotein on vancomycin protein binding in patients with burn injuries. J Burn Care Rehabil 10: 425-428.

44. Belley A, McKay GA, Arhin FF, Sarmiento I, Beaulieu S, et al. (2009) Oritavancin Disrupts Membrane Integrity of Staphylococcus aureus and VancomycinResistant Enterococci To Effect Rapid Bacterial Killing [down-pointing small open triangle]. Antimicrob Agent Chemother 53: 2687-2689.

45. McKay GA, Beaulieu S, Sarmiento I, Arhin FF, Parr TR Jr, et al. (2010) Impact of human serum albumin on oritavancin in vitro activity against enterococci. Antimicrob Agents Chemother 54: 5369-5371. 
Citation: Chaudhary M, Payasi A (2014) Battling the Methicillin-Resistant Staphylococcus aureus Biofilm Challenge with Vancoplus. J Microb Biochem Technol S10: 001. doi:10.4172/1948-5948.S10-001

Page 8 of 8

46. Soni A, Dwivedi VK, Chaudhary M (2009A) Efficacy of Vancoplus against intraabdominal infected mice: a novel fixed dose combination of ceftriaxone and vancomycin. J Biol Sci 9: 655-661.

47. Soni A, Dwivedi VK, Chaudhary M, Shrivastava SM (2009B) Antioxidant and blood brain barrier status in cerebrospinal fluid of bacterial meningitis rat model after Vancoplus treatment. J Med Sci 9: 194-201.

48. Herbert S, Barry P, Novick RP (2001) Subinhibitory clindamycin differentially inhibits transcription of exoprotein genes in Staphylococcus aureus. Infect Immun 69: 2996-3003.

49. Dumitrescu O, Boisset S, Badiou C, Bes M, Benito Y, et al. (2007) Effect of antibiotics on Staphylococcus aureus producing Panton-Valentine leukocidin. Antimicrob Agents Chemother 51: 1515-1519.

50. Dickgiesser N, Wallach U (1987) Toxic shock syndrome toxin-1 (TSST-1) influence of its production by subinhibitory antibiotic concentrations. Infection 15: $351-353$
51. Caiazza NC, O'Toole GA (2003) Alpha-toxin is required for biofilm formation by Staphylococcus aureus. J Bacteriol 185: 3214-3217

52. Howden BP, Smith DJ, Mansell A, Johnson PD, Ward PB, et al. (2008) Differen bacterial gene expression patterns and attenuated host immune responses are associated with the evolution of low-level vancomycin resistance during persistent methicillin-resistant Staphylococcus aureus bacteraemia. BMC Microbiol 8:39.

53. Schröder W, Bernhardt J, Marincola G, Klein-Hitpass L, Herbig A, et al. (2014) Altering gene expression by aminocoumarins: the role of DNA supercoiling in Staphylococcus aureus. BMC Genomics 15: 291.

54. Koszczol C, Bernardo K, Krönke M, Krut O (2006) Subinhibitory quinupristin dalfopristin attenuates virulence of Staphylococcus aureus. J Antimicrob Chemother 58: 564-574.

55. George NPE, Konstantopoulos K, Ross J (2007) Differential kinetics and molecular recognition mechanisms involved in early versus late growth phase Staphylococcus aureus cell binding to platelet layers under physiological shear conditions. J Infect Dis 196: 639-46.
This article was originally published in a special issue, Microbial Pathogenesis: Clinical Pathology handled by Editors. Dr. Syed Mohammad Wasim Jafri, The Aga Khan University Hospital, Pakistan, Dr. Asim Baig, The Aga Khan University Hospital, Pakistan 